\title{
Inkerinsuomen paradigmaattisen kompleksisuuden säilyminen kielikontaktissa ja attritiossa
}

\author{
HELKA RIIONHEIMO \\ Itä-Suomen yliopisto
}

Tiivistelmä. Tässä artikkelissa tarkastellaan suomen verbintaivutuksen paradigmaattisen kompleksisuuden säilymistä Viron inkerinsuomalaisilta kootussa haastatteluaineistossa. Paradigmaattisella kompleksisuudella tarkoitetaan sitä monimuotoisuutta, joka on kehittynyt kielihistorian aikana, kun sanan taivutusparadigman jäsenet ovat kehittyneet äänteenmuutosten vuoksi eri suuntiin. Artikkelissa verrataan verbien preesens- ja imperfektiparadigmoja inkerinsuomessa ja virossa ja osoitetaan, että inkerinsuomen verbintaivutus on näiltä osin erittäin kompleksista ja viron verbintaivutus siihen verrattuna paljon yksinkertaisempaa. Vertailun perusteella on valittu viisi kaikkein monimutkaisinta verbityyppiä, joiden aineistoesiintymiä analysoidaan paradigmaattisen kompleksisuuden kannalta. Tulokset osoittavat, että vaikka inkerinsuomen kompleksisuus on laajalti säilynyt, on aineistossa havaittavissa myös yksinkertaistumista. Muutokset ovat kuitenkin monitulkintaisia, sillä useimmiten kielensisäiset yksinkertaistumispaineet kietoutuvat yhteen viron kielen vaikutuksen kanssa.

Avainsanat: morfologia; morfofonologia; kompleksisuus; paradigmaattinen; kielikontakti; yksinkertaistuminen; inkerinsuomi; verbintaivutus; suomi; viro 


\section{Johdanto}

Tämä artikkeli kytkeytyy monen eri tutkimussuuntauksen piirissä käytävään keskusteluun kielen yksinkertaistumisesta. Kompleksisuustutkimuksessa korostetaan, että kielen yksinkertaistumisen taustalla voi olla kontaktiperäinen muutos, joka johtuu siitä, että osa kielen käyttäjistä on omaksunut kielen vasta aikuisiässä (ks. esim. Kusters 2003; Dahl2004: 110; Trudgill 2011: 40-41). Epätäydellinen lapsuudenaikainen kielenomaksuminen taas on ollut esillä toisen kielen omaksumisen tutkimuksessa tapauksissa, joissa vähemmistökielen puhujien vanhemmalta sukupolvelta saama syöte jää riittämättömäksi (ks. esim. Montrul 2010). Kielikontaktitutkimuksessa on puolestaan kiinnitetty huomiota tilanteisiin, joissa ilmenee eräänlaista negatiivista lainaamista: vähemmistökielestä katoaa rakenteita tai piirteitä, joilla ei ole vastinetta enemmistökielessä (ks. esim. Dorian 2006). Lisäksi yksinkertaistumiseen voi johtaa myös yksilöllinen ensikielen attritio eli äidinkielen hallinnan taantuminen sellaisessa elämäntilanteessa, jossa puhuja kommunikoi pääasiassa jollain myöhemmin omaksumallaan kielellä (ks. esim. Schmid 2011).

Tarkastelemani kielimuoto, Viroon toisen maailmansodan jälkeen asettuneen inkerinsuomalaissukupolven puhuma suomen kieli, on kompleksisuudesta ja yksinkertaistumisesta käydyn keskustelun valossa kiinnostava tutkimuskohde. Aineiston kielenpuhujat omaksuivat lapsuudessaan inkerinsuomen murteen Inkerinmaalla suomenkielisessä ympäristössä, mutta päädyttyään sodan jälkeen Neuvosto-Viroon he joutuivat vuosikymmenten ajan tukahduttamaan äidinkielensä ja puhumaan pääasiassa viroa. Inkerinsuomen ja viron kielikontaktiin ei siis tässä tilanteessa liity inkerinsuomen epätäydellistä omaksumista, mutta aineistossa on selviä merkkejä ensikielen attritiosta eli suomeksi puhumisen vaikeudesta. Tilanteessa voidaan siten nähdä ristivetoa: inkerinsuomen kompleksisetkin piirteet on omaksuttu osana äidinkieltä, mutta attritiotilanteessa äidinkielen yksinkertaistuminen on mahdollista varsinkin sellaisissa rakenteissa tai piirteissä, joiden osalta kontaktin dominoiva kieli viro on inkerinsuomea yksinkertaisempi. Aikaisemmin olen 
kuitenkin osoittanut, että attritiosta huolimatta inkerinsuomen preesens- ja imperfektimuotojen morfologinen kompleksisuus on monilta osin säilynyt (esim. Riionheimo 2007; 2013). Näyttää siis siltä, että ainakin morfologiassa kompleksisuus voi olla yksilön kielessä hyvinkin pysyvä ominaisuus.

Tässä artikkelissa keskityn morfologisen kompleksisuuden paradigmaattiseen ulottuvuuteen ja otan tarkasteltavaksi ne preesens- ja imperfektiparadigmat, joihin sisältyy eniten morfofonologisia vaihteluita. Käsittelen ensin yleisellä tasolla taivutusmorfologian paradigmansisäistä kompleksisuutta, minkä jälkeen kuvaan inkerinsuomen preesensja imperfektiparadigmoja ja kontrastoin ne viron taivutuksen kanssa. Lopuksi tarkastelen analyysiluvussa muutamien kaikkein kompleksisimpien verbien esiintymiä tutkimusaineistossa. Tavoitteena on selvittää, ovatko nämä kaikkein kompleksisimmat verbiparadigmat säilyneet vai muuttuneet inkerinsuomalaisten kielikontakti- ja attritiotilanteessa, ja tulokset täydentävät aikaisempaa tutkimustani, jossa olen tarkastellut preesens- ja imperfektimuotojen sisäistä eli syntagmaattista kompleksisuutta (Riionheimo 2013).

\section{Paradigmaattinen kompleksisuus taivutusmorfologiassa}

Kompleksisuus on monitahoinen ja monella tavoin käytetty käsite, mutta omassa tutkimuksessani käytän termiä tarkasti rajatulla tavalla. Viittaan kompleksisuudella ensinnäkin kielen rakenteessa ilmenevään monimutkaisuuteen, ja toiseksi tarkastelen kompleksisuutta erään morfologian osajärjestelmän, en koko kielen tai edes koko morfologisen systeemin kannalta (kompleksisuuden monista ulottuvuuksista ks. esim. Dahl 2004: 42-44; Karlsson ym. 2008; Miestamo 2008). Kolmanneksi käsittelen tätä osajärjestelmää yhden taivutusmorfologian kompleksisuuden parametrin, läpinäkyvyyden, suhteen (vrt. Kusters 2003: 26-30): taivutusmuotojen välillä ilmenevät morfofonologiset vaihtelut aiheuttavat sekä syntagmaattista että paradigmaattista läpinäkymättömyyttä, 
jota voidaan pitää kompleksisuutena. Sekä tässä teoreettisessa luvussa että seuraavassa deskriptiivisessä luvussa hahmottelen tapaa, jolla voidaan kuvata ja kontrastoida inkerinsuomen ja viron verbiparadigmojen kompleksisuutta.

Kun kuvataan synkronisesti jonkin kielen taivutusmorfologian tai yksittäisen morfologisen rakenteen kompleksisuutta, on tarpeen tarkastella ainakin systeemin tai rakenteen morfologisten komponenttien määrää, taivutusmuotojen sisäistä läpinäkyvyyttä ja taivutusmuotojen välille muodostuvaa äänteellistä suhdeverkostoa. Kompleksisuus voi ensinnäkin olla osittain puhtaasti määrällistä: sellainen kieli, jossa monet kieliopilliset kategoriat tai syntaktiset tehtävät ovat morfologisesti merkittyjä, on (morfologisesti) kompleksisempi kuin kieli, jossa on vähemmän morfologisesti merkittyjä kategorioita tai jossa kieliopillisia funktioita ilmaistaan perifrastisesti. Toiseksi sellainen kieli, jossa samaan sananmuotoon voi sisältyä useita kieliopillisia morfeemeja, on kompleksisempi kuin kieli, jossa sananmuodot koostuvat vain vartalosta ja yhdestä affiksista. Määrällinen kompleksisuuskäsite ei kuitenkaan yksin riitä kielen kuvaamiseen, sillä monimorfeemisten muotojen sisäinen kompleksisuus voi vaihdella huomattavasti: agglutinatiiviset rakenteet ovat suhteellisen yksinkertaisia, mutta fusionaalistuvissa rakenteissa vartalon ja affiksin välinen raja on hämärtynyt, mikä on lisännyt sananmuotojen sisäistä syntagmaattista kompleksisuutta.

Kolmas näkökulma morfologiseen kompleksisuuteen avautuu silloin, kun tarkastellaan sanan taivutusparadigmaa eli taivutusmuotojen muodostamaa sarjaa. Nimitän paradigmaattiseksi kompleksisuudeksi sitä monimuotoisuutta, joka on kehittynyt sanan taivutusvartaloihin kielihistorian aikana, kun taivutusparadigman jäsenet (perusmuodot ja eri taivutusmuodot) ovat etääntyneet äänteenmuutosten vuoksi toisistaan ja kun niiden välinen suhdeverkosto on monimutkaistunut (Riionheimo 2013). Tällainen verkostomainen kompleksisuus on luonteeltaan ennemmin laadullista kuin määrällistä ja ilmenee sanan eri taivutusvartaloiden välisinä äänteellisinä eroavuuksina. Vaikka taivutusmuotojen väliset erot ovat alun perin syntyneet sananmuodoissa tapahtuneiden 
äänteenmuutosten takia, ne ovat vähitellen alkaneet kantaa osaa koko taivutusmuodon kieliopillisesta merkityksestä. Synkronisesti vartaloiden välisillä eroilla voi olla semioottinen tehtävä, koska tietynlainen vartalo indikoi tiettyä taivutuspäätettä (allomorfian semioottisista tehtävistä ks. Anttila 1974; Paunonen 1976).

Kompleksiset paradigmat eivät ole syntyperäisen kielenpuhujan näkökulmasta vaikeita, ja sopivissa olosuhteissa huomattavakin kompleksisuus voi säilyä kielessä satojen vuosien ajan (ks. esim. Dahl 2004: 290). McWhorter (2008) pitää kompleksisuuden säilymistä luonnollisen kielen luontaisena ja pitkään säilyvänä ominaisuutena, mikäli kieli välittyy sukupolvelta toiselle lapsuudenaikaisen kielenomaksumisen kautta. Toisaalta yksittäisten kompleksisten rakenteiden yksinkertaistuminen on kuitenkin tavallinen (joskaan ei yksinomainen) kehityslinja kielten historiassa. Yksi mahdollinen kielenmuutosten ketju etenee niin, että foneettisehtoisena alkanut äänteenmuutos johtaa vähitellen morfofonologiseen ja allomorfiseen vaihteluun, jota seuraa sitten morfologinen "reaktio" eli kompleksisen vaihtelun tasoittuminen esimerkiksi jonkin läpinäkyvän taivutuspäätteen analogisen yleistymisen kautta (ks. esim. Paunonen 2003: 190). Suomen morfologian tutkimuksessa on esitetty oletus, että suomen taivutustyypeistä kaikkein altteimpia tämäntapaisille muutoksille ovat sellaiset paradigmat, joissa ilmenee eniten morfofonologista tai allomorfista vaihtelua (Paunonen mts. 208). Tässä artikkelissa pyrin selvittämään, pitääkö oletus kompleksisten taivutusparadigmojen yksinkertaistumisherkkyydestä paikkansa inkerinsuomalaisten kielikontaktiaineistossa.

\section{Preesens ja imperfektiparadigmat inkerinsuomessa ja virossa}

Seuraavaksi luon kuvaa siitä, millaiset taivutussysteemit inkerinsuomalaisilla on ollut kielikontaktissa ulottuvillaan. Tavoitteena on osoittaa, että inkerinsuomen kaltaisessa puhutussa kielimuodossa verbintaivutus on morfofonologisten vaihteluiden vuoksi hyvin kompleksista ja 
että (standardi)viro on näiden taivutusmuotojen osalta inkerinsuomeen verrattuna huomattavan yksinkertainen. Olen aikaisemmin kuvannut inkerinsuomen verbintaivutuksen syntagmaattista ja allomorfista kompleksisuutta (Riionheimo 2013), ja nyt keskityn myönteisen preesens- ja imperfektitaivutuksen paradigmaattiseen kompleksisuuteen.

\subsection{Inkerinsuomen preesens ja imperfekti}

Inkerinsuomen kuvaus nojaa lähinnä Porkan (1885) ja Ruoppilan (1955) tutkimuksiin sekä eri aikoina julkaistuihin Inkerin murteiden kielennäytteisiin (tarkemmin ks. Riionheimo 2007: 46-47). Kuvaustapa perustuu kokonaisten taivutusmuotojen muodostamiin sarjoihin, joten se muistuttaa suomalaisen kenttämorfologian kuvausmalleja (vrt. esim. Paunonen 1976; 2003). Kuvaus keskittyy kaksitavuisiin, astevaihtelutapauksissa suoran astevaihtelun alaisiin verbeihin, joten pois jäävät esimerkiksi yksitavuiset verbit ja sellaiset kaksivartaloiset johdostyypit, joille on ominaista käänteinen astevaihtelu (kuten supistumaverbit ja ele- ja ne-johdokset).

Inkerinsuomen preesenstaivutukseen tuottavat kompleksisuutta ne äänteenmuutokset, jotka ovat muokanneet persoonamuotoja eri suuntiin. Yksinkertaisin paradigma on niillä verbeillä, joiden taivutuksessa ei ilmene lainkaan äännevaihteluja ja joilla on kaikissa persoonissa samanlainen vartalo (pyöriä-tyyppi). Kaikissa muissa verbityypeissä paradigmat ovat epäsymmetrisiä, sillä niin yksikössä kuin monikossakin 1. ja 2. persoonien vartalot poikkeavat 3. persoonien vartaloista. Tätä epäsymmetriaa luovat useat morfofonologiset vaihtelut: astevaihtelu (tahtoa), yleisgeminaatio ( $p$ uhua) ja vartalonloppuisen ee:n labiaalistuminen (päästä). Kolmannet persoonat eroavat selvimmin 1. ja 2. persoonista niillä verbeillä, joiden vartalossa astevaihtelu yhdistyy yleisgeminaatioon (repiä) tai labiaalistumiseen (lähteä). On myös pieni joukko verbejä, joiden taivutusmuodoissa ilmenee kolme morfofonologista vaihtelua (astevaihtelu, yleisgeminaatio ja labiaalistuminen) ja joiden paradigmassa persoonien välinen epäsymmetria on suurimmillaan (lukea-tyyppi). 
ASETELMA 1. Inkerinsuomen preesensin persoonamuotojen

paradigmaattinen kompleksisuus

Äännevaihtelut merkitty seuraavasti: lihavointi = vahva aste, alleviivaus $=$ yleisgeminaatio, kursiivi $=$ labiaalistuminen

\begin{tabular}{|c|c|c|c|c|}
\hline $\begin{array}{l}\text { Ei lainkaan } \\
\text { morfofonologisia } \\
\text { vaihteluita (pyöriä) }\end{array}$ & $\begin{array}{l}\text { yks. } 1 . \\
\text { yks. } 2 . \\
\text { yks. } 3 .\end{array}$ & $\begin{array}{l}\text { pyöri|n } \\
\text { pyöri|t } \\
\text { pyöri|i }\end{array}$ & $\begin{array}{l}\text { mon. } 1 . \\
\text { mon. } 2 . \\
\text { mon. } 3 .\end{array}$ & $\begin{array}{l}\text { pyöri|mmä } \\
\text { pyöri|ttä } \\
\text { pyöri|it }\end{array}$ \\
\hline \multirow[t]{2}{*}{ Astevaihtelu (tahtoa) } & $\begin{array}{l}\text { yks. } 1 . \\
\text { yks. } 2 .\end{array}$ & $\begin{array}{l}\text { taho|n } \\
\text { taho|t }\end{array}$ & $\begin{array}{l}\text { mon. } 1 . \\
\text { mon. } 2 .\end{array}$ & $\begin{array}{l}\text { taho|mma } \\
\text { taho|tta }\end{array}$ \\
\hline & yks. 3. & tahto|o & mon. 3. & tahto|ot \\
\hline \multirow[t]{3}{*}{ Yleisgeminaatio (puhua) } & yks. 1. & puhu|n & mon. 1. & puhu|mma \\
\hline & yks. 2. & puhu|t & mon. 2. & puhu|tta \\
\hline & yks. 3. & puhhu|u & mon. 3 . & puhhu|ut \\
\hline \multirow{3}{*}{$\begin{array}{l}\text { Labiaalistuminen } \\
\text { (päästä) }\end{array}$} & yks. 1. & piäse|n & mon. 1. & piäse|mmä \\
\hline & yks. 2. & piäse|t & mon. 2 & piäse|ttä \\
\hline & yks. 3. & piäsö $\mid \ddot{o}$ & mon. 3. & piäsö|öt \\
\hline \multirow{3}{*}{$\begin{array}{l}\text { Astevaihtelu + } \\
\text { yleisgeminaatio (repiä) }\end{array}$} & yks. 1. & revi|n & mon. 1. & revi|mmä \\
\hline & yks. 2. & revi|t & mon. 2. & revi|ttä \\
\hline & yks. 3. & reppi|i & mon. 3. & reppi|it \\
\hline \multirow{3}{*}{$\begin{array}{l}\text { Astevaihtelu + } \\
\text { labiaalistuminen (lähteä) }\end{array}$} & yks. 1. & lähe|n & mon. 1. & lähe|mmä \\
\hline & yks. 2. & lähe|t & mon. 2 & lähet|tä \\
\hline & yks. 3. & lähtö|ö & mon. 3. & lähtö|öt \\
\hline \multirow{3}{*}{$\begin{array}{l}\text { Astevaihtelu }+ \\
\text { yleisgeminaatio }+ \\
\text { labiaalistuminen (lukea) }\end{array}$} & yks. 1. & luve $\mid \mathrm{n}$ & mon. 1. & luve|mma \\
\hline & yks. 2. & luve|t & mon. 2. & luve|tta \\
\hline & yks. 3. & lukko|o & mon. 3. & lukko|ot \\
\hline
\end{tabular}

Myös imperfektiparadigmoissa on persoonamuotojen välisiä eroja, jotka aiheutuvat pitkälti samoista morfofonologisista vaihteluista kuin preesensissäkin. Yksinkertaisimmat paradigmat ovat jälleen niillä verbeillä, joiden vartalossa ei tapahdu äänteellisiä muutoksia (pyöriä-tyyppi). Suoran astevaihtelun alaisilla verbeillä persoonamuotojen välillä on samanlainen ero kuin preesensissä eli heikkoasteiset 1. ja 2. persoonat erottuvat vahva-asteisista 3. persoonista (tahtoa-tyyppi). Yleisgeminaatio sen 
sijaan koskettaa imperfektissä vain monikon 3. persoonan muotoja, joiden lopussa on joko pitkä $i$-vokaali tai diftongi (puhua-tyyppi), ja erottaa siten nämä muodot muusta persoonaparadigmasta. Kaikkein mutkikkain paradigma on niillä verbeillä, joille ovat ominaisia sekä astevaihtelu että yleisgeminaatio: tällöin 1. ja 2. persoonat ovat heikkoasteisia, yksikön 3. persoona vahva-asteinen ja monikon 3. persoona vahva-asteinen ja geminoitunut (repiä-tyyppi).

Asetelma 2. Inkerinsuomen imperfektin persoonamuotojen

paradigmaattinen kompleksisuus

Äännevaihtelut merkitty seuraavasti: lihavointi = vahva aste, alleviivaus $=$ yleisgeminaatio, kursiivi $=$ labiaalistuminen

\begin{tabular}{|c|c|c|c|c|}
\hline $\begin{array}{l}\text { Ei lainkaan } \\
\text { morfofonologisia } \\
\text { vaihteluita (pyöriä) }\end{array}$ & $\begin{array}{l}\text { yks. } 1 . \\
\text { yks. } 2 . \\
\text { yks. } 3 .\end{array}$ & $\begin{array}{l}\text { pyör|i|n } \\
\text { pyör|i|t } \\
\text { pyör|i }\end{array}$ & $\begin{array}{l}\text { mon. } 1 . \\
\text { mon. } 2 \text {. } \\
\text { mon. } 3 \text {. }\end{array}$ & $\begin{array}{l}\text { pyör|i|mmä } \\
\text { pyör|i|ttä } \\
\text { pyör|i|it }\end{array}$ \\
\hline \multirow[t]{2}{*}{ Astevaihtelu (tahtoa) } & $\begin{array}{l}\text { yks. } 1 . \\
\text { yks. } 2 .\end{array}$ & $\begin{array}{l}\text { taho|i|n } \\
\text { taho|i|t }\end{array}$ & $\begin{array}{l}\text { mon. } 1 . \\
\text { mon. } 2 .\end{array}$ & $\begin{array}{l}\text { taho|i|mma } \\
\text { taho|i|tta }\end{array}$ \\
\hline & yks. 3. & tahto|i & mon. 3. & tahto|i|t \\
\hline \multirow[t]{2}{*}{ Yleisgeminaatio (puhua) } & $\begin{array}{l}\text { yks. } 1 . \\
\text { yks. } 2 .\end{array}$ & $\begin{array}{l}\text { puhu|i|n } \\
\text { puhu|i|t }\end{array}$ & $\begin{array}{l}\text { mon. } 1 . \\
\text { mon. } 2 \text {. }\end{array}$ & $\begin{array}{l}\text { puhu|i } \mid \mathrm{mma} \\
\text { puhu|i|tta }\end{array}$ \\
\hline & yks. 3. & puhu|i & mon. 3. & puhhu|i|t \\
\hline \multirow[t]{2}{*}{$\begin{array}{l}\text { Astevaihtelu + } \\
\text { yleisgeminaatio (repiä) }\end{array}$} & $\begin{array}{l}\text { yks. } 1 . \\
\text { yks. } 2 .\end{array}$ & $\begin{array}{l}\operatorname{rev}|\mathrm{i}| \mathrm{n} \\
\mathrm{rev}|\mathrm{i}| \mathrm{t}\end{array}$ & $\begin{array}{l}\text { mon. } 1 . \\
\text { mon. } 2 .\end{array}$ & $\begin{array}{l}\text { rev|i|mmä } \\
\text { rev|i|ttä }\end{array}$ \\
\hline & yks. 3. & $\operatorname{rep} \mid \mathrm{i}$ & mon. 3 . & reppilit \\
\hline
\end{tabular}

Inkerinsuomen persoonataivutuksen paradigmaattinen kompleksisuus korostuu entisestään silloin, kun imperfekti- ja preesensmuotoja verrataan toisiinsa. Alempana asetelmassa 3 taulukon sarakkeet kuvaavat niitä äännevaihteluita, jotka aiheuttavat eroja eri persoonamuotojen välillä: paradigmatyypissä A ei ilmene vaihteluita, tyypissä B esiintyy astevaihtelu, tyypissä C yleisgeminaatio ja tyypissä D sekä astevaihtelu että yleisgeminaatio. Taulukon riveillä puolestaan kuvataan sellaisia vaihteluita, jotka aiheuttavat eroja preesens- ja imperfektivartaloiden välille. 
1-tyyppiin kuuluvilla verbeillä vartalovokaali säilyy muuttumattomana imperfektin $i: n$ edellä (pyöreään vokaaliin päättyvät vartalot), 2-tyypin verbeillä vartalovokaali sulautuu imperfektin tunnukseen ( $i$-vartaloiset verbit) ja 3-tyypin verbeillä joko vartalovokaali katoaa imperfektissä tai vartalon $a$ muuttuu $o$ :ksi ( $a$ - ja $\ddot{a}$-vartaloiset verbit). 4-tyypin verbeillä (eli $e$-vartaloisilla verbeillä) on preesensin 3. persoonan muodoissa pitkä $e$ labiaalistunut oo:ksi tai öö:ksi ja imperfektissä vartalon $e$ kadonnut tunnuksen edellä. Viimeiseen eli 5-tyyppiin kuuluvat ne verbit, joiden vartalovokaali $a$ tai $\ddot{a}$ on kadonnut imperfektimuodossa ja vartalon $t$ on sen jälkeen muuttunut $s$ :ksi $i$-tunnuksen edellä.

Asetelma 3 paljastaa, että verbiparadigmojen välillä on preesens- ja imperfektitaivutuksen vartalonmuodostuksessa suuria eroja; nämä erot on merkitty asetelmaan pystysuoran katkoviivan avulla (vaakasuorat katkoviivat taas osoittavat persoonamuotojen välisiä eroja). 1- ja 2-tyypin verbeillä preesensin ja imperfektin erot ovat vähäisiä: jos vartalossa ei ilmene yleisgeminaatiota, eroja ei ole lainkaan (tyypit A1 istua ja A2 pyöriä sekä B1 tahtoa ja B2 vahtia), ja yleisgeminaation alaisilla verbeillä ainoa ero on yksikön 3. persoonassa, jossa yleisgeminaatio ilmenee preesensissä mutta ei imperfektissä (tyypit C1 puhua ja C2 läsiä sekä D1 kutoa ja D2 repiä). 3-tyypin verbeillä kaikki preesens- ja imperfektivartalot poikkeavat toisistaan vähintään vartalovokaalin kadon tai muuttumisen vuoksi (tyypit A3 laulaa ja B3 löytää), ja mikäli verbi on yleisgeminaation alainen, yksikön 3. persoonassa preesens- ja imperfektivartaloa erottaa vokaalinmuutoksen lisäksi preesensissä ilmenevä geminoituminen (tyypit C3 elää ja D3 jakaa). 4-tyypissä preesens- ja imperfektivartaloita erottaa kaikissa persoonissa vartalovokaalin kato ja yksikön ja monikon 3. persoonissa lisäksi vartalovokaalin labiaalistuminen preesensissä (tyypit A4 päästä, B4 kulkea, C4 tulla ja D4 lukea). 5-tyypissä (tietää) kaikkien persoonien imperfektivartalo poikkeaa preesensvartalosta sekä vartalovokaalin katoamisen että $t>s$-muutoksen vuoksi. 
ASETELMA 3. Verbien preesens- ja imperfektiparadigmat rinnakkain

\begin{tabular}{|c|c|c|c|c|}
\hline $\begin{array}{l}\text { Vartalovokaalin } \\
\text { muutos }\end{array}$ & \multicolumn{2}{|c|}{$\begin{array}{l}\text { A } \\
\text { Ei vaihteluita }\end{array}$} & \multicolumn{2}{|c|}{$\begin{array}{l}\text { B } \\
\text { Astevaihtelu }\end{array}$} \\
\hline \multirow{6}{*}{$\begin{array}{l}1 \\
\text { Ei } \\
\text { vartalovokaalin } \\
\text { muutoksia } \\
\text { i-tunnuksen } \\
\text { edellä }\end{array}$} & \multicolumn{2}{|c|}{ istua } & \multicolumn{2}{|c|}{ tahtoa } \\
\hline & \multirow{4}{*}{\begin{tabular}{|l|} 
istu|n \\
istu|t \\
istu|i \\
istu|mma \\
istu|tta \\
istu|it
\end{tabular}} & \multirow{4}{*}{$\begin{array}{l}\text { istu|i|n } \\
\text { istu|i|t } \\
\text { istu|i } \\
\text { istu|i|mma } \\
\text { istu|i|tta } \\
\text { istu|i|it }\end{array}$} & $\begin{array}{l}\text { taho|n } \\
\text { taho|t }\end{array}$ & $\begin{array}{l}\text { taho|i|n } \\
\text { taho|i|t }\end{array}$ \\
\hline & & & tahto|o & tahto|i \\
\hline & & & $\begin{array}{l}\text { taho|mma } \\
\text { taho|tta }\end{array}$ & $\begin{array}{l}\text { taho|i|mma } \\
\text { taho|i|tta }\end{array}$ \\
\hline & & & tahto|ot & tahto|i|t \\
\hline & \multicolumn{2}{|c|}{ vaihteluita yhteensä 0} & \multicolumn{2}{|c|}{ vaihteluita yhteensä 1} \\
\hline \multirow{7}{*}{$\begin{array}{l}2 \\
i \text {-vartaloiset } \\
\text { verbit (vartalo- } \\
\text { vokaali sulautuu } \\
i \text {-tunnuksen) }\end{array}$} & \multicolumn{2}{|c|}{ pyöriä } & \multicolumn{2}{|c|}{ vahtia } \\
\hline & \multirow{5}{*}{$\begin{array}{l}\text { pyöri|n } \\
\text { pyöri|t } \\
\text { pyöri|i } \\
\text { pyöri|mmä } \\
\text { pyöri|ttä } \\
\text { pyöri|it }\end{array}$} & \multirow{5}{*}{$\begin{array}{l}\text { pyör|i|n } \\
\text { pyör|i|t } \\
\text { pyör|i } \\
\text { pyör|i|mmä } \\
\text { pyör|i|ttä } \\
\text { pyör|i|it }\end{array}$} & vahin & vah|i|n \\
\hline & & & vahit & vah|i|t \\
\hline & & & vahti|i & vaht|i \\
\hline & & & $\begin{array}{l}\text { vahi|mma } \\
\text { vahi|tta }\end{array}$ & $\begin{array}{l}\text { vah|i|mma } \\
\text { vah|i|tta }\end{array}$ \\
\hline & & & vahti|it & vaht|i|it \\
\hline & \multicolumn{2}{|c|}{ vaihteluita yhteensä 1} & \multicolumn{2}{|c|}{ vaihteluita yhteensä 2} \\
\hline \multirow{8}{*}{$\begin{array}{l}3 \\
\text { Vartalovokaalin } \\
\text { muutoksia } i: \mathrm{n} \\
\text { edellä (kato tai } \\
a>0 \text { ) }\end{array}$} & \multicolumn{2}{|c|}{ laulaa } & \multicolumn{2}{|c|}{ löytää } \\
\hline & \multirow{6}{*}{$\begin{array}{l}\text { laula|n } \\
\text { laula|t } \\
\text { laula|a } \\
\text { laula|mma } \\
\text { laula|tta } \\
\text { laula|at }\end{array}$} & \multirow{6}{*}{$\begin{array}{l}\text { laulo|i|n } \\
\text { laulo|i|t } \\
\text { laulo|i } \\
\text { laulo|i|mma } \\
\text { laulo|i|tta } \\
\text { laulo|i|t }\end{array}$} & ala|n & alo|i $\mid \mathrm{n}$ \\
\hline & & & ala $\mid \mathrm{t}$ & alo|i $\mid \mathrm{t}$ \\
\hline & & & alka|a & alko|i \\
\hline & & & ala|mma & alo|i|mma \\
\hline & & & ala|tta & alo|i|tta \\
\hline & & & alka|at & alko|i|t \\
\hline & \multicolumn{2}{|c|}{ vaihteluita yhteensä 1} & \multicolumn{2}{|c|}{ vaihteluita yhteensä 2} \\
\hline \multirow{8}{*}{$\begin{array}{l}4 \\
e \text {-vartaloiset } \\
\text { verbit (labiaalis- } \\
\text { tuminen } \\
\text { preesensissä; } \\
\text { vartalovokaalin } \\
\text { kato imper- } \\
\text { fektissä) }\end{array}$} & \multicolumn{2}{|c|}{ pä̈̈stä } & \multicolumn{2}{|c|}{ kulkea } \\
\hline & piäse|n & \multirow{6}{*}{$\begin{array}{l}\text { piäs|i|n } \\
\text { piäs|i|t } \\
\text { piäs } \\
\text { piäs|i|mmä } \\
\text { piäs|i|ttä } \\
\text { piäs|i|it }\end{array}$} & kule|n & $\operatorname{kul}|\mathrm{i}| \mathrm{n}$ \\
\hline & piäse|t & & kule|t & kul $|\mathbf{i}| \mathrm{t}$ \\
\hline & piäsö]ö & & kulko|o & kulk $|\mathrm{i}|$ \\
\hline & piäse|mmä & & kule|mma & $\mathrm{kul}|\mathrm{i}| \mathrm{mma}$ \\
\hline & piäse|ttä & & kule|tta & kul|i $\mid$ tta \\
\hline & piäsö|öt & & kulko|ot & kulk|i|it \\
\hline & \multicolumn{2}{|c|}{ vaihteluita yhteensä 2} & \multicolumn{2}{|c|}{ vaihteluita yhteensä 3} \\
\hline
\end{tabular}


Äännevaihtelut merkitty seuraavasti: lihavointi = vahva aste, alleviivaus = yleisgeminaatio, kursiivi $=$ labiaalistuminen, kaksoisalleviivaus $=\mathrm{t} \sim \mathrm{s}$ vaihtelu

\begin{tabular}{|c|c|c|c|}
\hline \multicolumn{2}{|c|}{$\begin{array}{l}\mathrm{C} \\
\text { Yleisgeminaatio }\end{array}$} & \multicolumn{2}{|c|}{$\begin{array}{l}\text { D } \\
\text { Astevaihtelu ja yleisgeminaatio }\end{array}$} \\
\hline \multicolumn{2}{|c|}{ puhua } & \multicolumn{2}{|c|}{ kutoa } \\
\hline puhu|n & \multirow{4}{*}{$\begin{array}{l}\text { puhu|i|n } \\
\text { puhu|i|t } \\
\text { puhu|i } \\
\text { puhu|i|mma } \\
\text { puhu|i|tta }\end{array}$} & kuo|n & kuo|i|n \\
\hline puhu|t & & kuolt & kuo|i|t \\
\hline puhhulu & & kutto|o & kuto|i \\
\hline $\begin{array}{l}\text { puhu|mma } \\
\text { puhu|tta }\end{array}$ & & $\begin{array}{l}\text { kuo|mma } \\
\text { kuo|tta }\end{array}$ & $\begin{array}{l}\text { kuo|i|mma } \\
\text { kuo|i|tta }\end{array}$ \\
\hline puhhu|ut & puhhu|i|t & kutto|ot & kutto $|\mathrm{i}| \mathrm{t}$ \\
\hline \multicolumn{2}{|c|}{ vaihteluita yhteensä 1} & \multicolumn{2}{|c|}{ vaihteluita yhteensä 2} \\
\hline \multicolumn{2}{|c|}{ läsiä 'sairastaa' } & \multicolumn{2}{|c|}{ repiä } \\
\hline $\begin{array}{l}\text { läsi|n } \\
\text { läsilt }\end{array}$ & \multirow{3}{*}{$\begin{array}{l}\text { läs|i|n } \\
\text { läs }|\mathrm{i}| \mathrm{t} \\
\text { läs } \mid \mathrm{i} \\
\text { läs|i|mmä } \\
\text { läss|i|ttä }\end{array}$} & $\begin{array}{l}\text { revi|n } \\
\text { revilt }\end{array}$ & $\begin{array}{l}\text { rev|i|n } \\
\text { revilit }\end{array}$ \\
\hline lässili & & reppi i & rep $\mid i$ \\
\hline $\begin{array}{l}\text { läsi|mmä } \\
\text { läsi|ttä }\end{array}$ & & $\begin{array}{l}\text { revi|mmä } \\
\text { revi|ttä }\end{array}$ & $\begin{array}{l}\text { rev|i } \mid \mathrm{mmä} \\
\operatorname{rev}|\mathrm{i}| \mathrm{ttä}\end{array}$ \\
\hline lässi|it & läss $|i| i t$ & reppilit & reppilit \\
\hline \multicolumn{2}{|c|}{ vaihteluita yhteensä 2} & \multicolumn{2}{|c|}{ vaihteluita yhteensä 3} \\
\hline \multicolumn{2}{|c|}{ elää } & \multicolumn{2}{|c|}{ jakaa } \\
\hline $\begin{array}{l}\text { elä|n } \\
\text { elä|t }\end{array}$ & \multirow{3}{*}{$\begin{array}{l}\text { e|l|in } \\
\text { el|i|t } \\
\text { el } \mid \mathrm{i} \\
\text { el }|\mathrm{i}| \mathrm{mmä} \\
\text { el }|\mathrm{i}| \mathrm{t} \text { ä }\end{array}$} & $\begin{array}{l}\text { jaa } \mid \mathrm{n} \\
\text { jaa } \mid \mathrm{t}\end{array}$ & $\begin{array}{l}\text { jao }|\mathrm{i}| \mathrm{n} \\
\text { jao }|\mathrm{i}| \mathrm{t}\end{array}$ \\
\hline ellälä & & jakka|a & jako|i \\
\hline $\begin{array}{l}\text { elä|mmä } \\
\text { elä|ttä }\end{array}$ & & $\begin{array}{l}\text { jaa|mma } \\
\text { jaa|tta }\end{array}$ & $\begin{array}{l}\text { jao|i } 1 \mathrm{mma} \\
\text { jao|i|tta }\end{array}$ \\
\hline ellä|ät & ell $|\mathrm{i}| \mathrm{it}$ & jakka|at & jakko|i|t \\
\hline \multicolumn{2}{|c|}{ vaihteluita yhteensä 2} & \multicolumn{2}{|c|}{ vaihteluita yhteensä 3} \\
\hline \multicolumn{2}{|c|}{ tulla } & \multicolumn{2}{|c|}{ lukea } \\
\hline $\begin{array}{l}\text { tule } \mid \mathrm{n} \\
\text { tule } \mid \mathrm{t}\end{array}$ & \multirow{3}{*}{$\begin{array}{l}\text { tul }|\mathrm{i}| \mathrm{n} \\
\text { tul|i|t } \\
\text { tul|i } \\
\text { tul }|\mathrm{i}| \mathrm{mma} \\
\text { tul } \mathrm{i} \mid \mathrm{tta}\end{array}$} & $\begin{array}{l}\text { lue } \mid \mathrm{n} \\
\text { lue } \mid \mathrm{t}\end{array}$ & $\begin{array}{l}\operatorname{lu}|\mathrm{i}| \mathrm{n} \\
\mathrm{lu}|\mathrm{i}| \mathrm{t}\end{array}$ \\
\hline tullo $o$ & & lukkolo & luk $\mid i$ \\
\hline $\begin{array}{l}\text { tule|mma } \\
\text { tule|tta }\end{array}$ & & $\begin{array}{l}\text { lue|mma } \\
\text { lue|tta }\end{array}$ & $\begin{array}{l}\text { lu|i } \mid \text { mma } \\
\text { lu|i } \mid \text { tta }\end{array}$ \\
\hline tullo $\mid$ ot & tull $|\mathrm{i}| \mathrm{it}$ & lukkoot & $\operatorname{lukk}|\mathbf{i}|$ it \\
\hline \multicolumn{2}{|c|}{ vaihteluita yhteensä 3} & \multicolumn{2}{|c|}{ vaihteluita yhteensä 4} \\
\hline
\end{tabular}




\begin{tabular}{|c|c|c|c|}
\hline $\begin{array}{l}\text { Vartalovokaalin } \\
\text { muutos }\end{array}$ & $\begin{array}{l}\text { A } \\
\text { Ei vaihteluita }\end{array}$ & \multicolumn{2}{|c|}{$\begin{array}{l}\text { B } \\
\text { Astevaihtelu }\end{array}$} \\
\hline \multirow{6}{*}{$\begin{array}{l}5 \\
t i \sim s i \text {-verbit } \\
\text { (imperfektissä } \\
\text { vartalovokaalin } \\
\text { kato ja } t>s \text { ) }\end{array}$} & & \multicolumn{2}{|c|}{ tietää } \\
\hline & & $\begin{array}{l}\text { tiiä|n } \\
\text { tiiä|t }\end{array}$ & $\begin{array}{l}\text { ties }|\mathrm{i}| \mathrm{n} \\
\text { ties } \underline{\underline{s}}|\mathrm{i}| \mathrm{t}\end{array}$ \\
\hline & & tietä|ä & ties $\mid \mathrm{i}$ \\
\hline & & $\begin{array}{l}\text { tiiä|mmä } \\
\text { tiiä|ttä }\end{array}$ & $\begin{array}{l}\text { ties } \mid \text { |i } \mid \text { mmä } \\
\text { ties }|\mathrm{i}| \text { ttä }\end{array}$ \\
\hline & & tietä|ät & ties $\underline{\underline{s}}$ i|it \\
\hline & & \multicolumn{2}{|c|}{ vaihteluita yhteensä 3} \\
\hline
\end{tabular}

Lopuksi on syytä kiinnittää huomiota siihen, että preesens- ja imperfektivartaloiden väliset erot yhdistyvät eri tavoin persoonamuotojen välisiin eroihin. Asetelman 3 katkoviivoituksesta näkyy, että joissain verbityypeissä paradigmat ovat hyvin yhdenmukaisia, kun taas toisissa tyypeissä, joissa esiintyy useita morfofonologisia äännevaihteluita, on runsaasti eroja sekä eri persoonamuotojen että preesens- ja imperfektivartaloiden välillä. Mitä enemmän paradigman visuaalisessa kuvauksessa on tarvittu katkoviivoja, sitä enemmän verbin paradigmassa on persoonamuotojen välisiä tai preesens- ja imperfektimuotojen välisiä eroavuuksia. Paradigmojen sirpaleisuus korreloi luonnollisesti verbin taivutuksessa esiintyvien morfofonologisen vaihteluiden määrän kanssa, koska kukin vaihtelu tuottaa erityyppisiä paradigmaattisia eroja. Tällä perusteella paradigmaattisesti kompleksisimpia ovat kolme äännevaihtelua sisältävät tyypit B4 kulkea, B5 tietää, C4 tulla ja D3 jakaa sekä neljän vaihtelun tyyppi D4 lukea, ja luvussa 4 tarkastelen näiden viiden verbityypin esiintymiä inkerinsuomalaisten kielikontaktiaineistossa.

\subsection{Viron preesens ja imperfekti}

Seuraava viron preesens- ja imperfektiparadigmojen kuvaus nojaa standardikielen kieliopillisiin kuvauksiin, erityisesti deskriptiiviseen kielioppiin (EKG I 1995) ja suomea ja viroa kontrastoiviin kuvauksiin (Remes 1983; 2009), joten se ei ole täysin yhteismitallinen inkerinsuomen 


\begin{tabular}{|l|l|}
\hline C & D \\
Yleisgeminaatio & Astevaihtelu ja yleisgeminaatio \\
\hline & \\
& \\
& \\
& \\
\hline
\end{tabular}

murteenmukaisen taivutuksen kuvauksen kanssa. Havainnollistan muutamien esimerkkiparadigmojen avulla sitä, millaista allomorfiaa viron preesens- ja imperfektitaivutuksessa ilmenee ja millaisia verkostoja taivutusmuotojen välille muodostuu. Tämä esitys antaa karkean kuvan viron taivutuksesta, sillä siinä ei ole otettu huomioon verbien muuta konjugaatiota eikä virolle ominaista kestovaihtelua; kuvauksessa astevaihtelu-termi viittaa klusiilien astevaihteluun. Myös viron murteiden ja puhekielen piirteet jäävät kuvauksen ulkopuolelle.

Viron preesens- ja imperfektitaivutusta havainnollistaa asetelma 4. Inkerinsuomeen verrattuna viron taivutus on siinä suhteessa erilaista, että molemmissa aikamuodoissa persoonapäätteet liitetään kaikissa persoonissa samanlaiseen vartaloon. Inkerinsuomessa persoonamuotojen välisiä eroja aiheuttavat ensinnäkin yleisgeminaatio ja vartalon $e: n$ labiaalistuminen, mutta virossa näitä äännevaihteluita ei ole. Toinen syy yhdenmukaisiin persoonaparadigmoihin ovat virossa tapahtuneet asteyleistykset: heikkenevän astevaihtelun alaisilla verbeillä (joilla $d a$-infinitiivi on vahva-asteinen) preesensparadigmoihin on yleistetty heikkoasteinen ja imperfektiparadigmoihin vahva-asteinen vartalo. Astevaihtelu osoittaa siten virossa aikamuotojen välisiä eroja, kun taas inkerinsuomen astevaihtelu erottaa persoonia. 
Asetelma 4. Viron preesens- ja imperfektitaivutus aktiivin persoonamuodoissa. Astevaihtelulla viitataan suomen astevaihtelua vastaavaan klusiilien kesto- ja laatuvaihteluun

\begin{tabular}{|c|c|c|c|}
\hline Verbien tyypit & Persoona & Preesens & Imperfekti \\
\hline $\begin{array}{l}\text { Yksivartaloiset } \\
\text { astevaihteluttomat } \\
\text { verbit (elama 'elää) }\end{array}$ & $\begin{array}{l}\text { yks. } 1 . \\
\text { yks. } 2 . \\
\text { yks. } 3 . \\
\text { mon. } 1 . \\
\text { mon. } 2 . \\
\text { mon. } 3 .\end{array}$ & $\begin{array}{l}\text { ela|n } \\
\text { ela|d } \\
\text { ela|b } \\
\text { ela|me } \\
\text { ela|te } \\
\text { ela|vad } \\
\end{array}$ & $\begin{array}{l}\text { ela|si|n } \\
\text { ela|si|d } \\
\text { ela|s } \\
\text { ela|si|me } \\
\text { ela|si|te } \\
\text { ela|si|d }\end{array}$ \\
\hline $\begin{array}{l}\text { Yksivartaloiset } \\
\text { astevaihteluverbit } \\
\text { (lugema 'lukea') }\end{array}$ & $\begin{array}{l}\text { yks. } 1 . \\
\text { yks. } 2 . \\
\text { yks. } 3 . \\
\text { mon. } 1 . \\
\text { mon. } 2 . \\
\text { mon. } 3 .\end{array}$ & $\begin{array}{l}\text { loe|n } \\
\text { loe|d } \\
\text { loe|b } \\
\text { loe|me } \\
\text { loe|te } \\
\text { loe|vad } \\
\end{array}$ & $\begin{array}{l}\text { luge|si|n } \\
\text { luge|si|d } \\
\text { luge|s } \\
\text { luge|si|me } \\
\text { luge|si|te } \\
\text { luge|si|d }\end{array}$ \\
\hline $\begin{array}{l}\text { Kaksivartaloiset verbit, } \\
\text { joilla ei astevaihtelua } \\
\text { (laulma 'laulaa') }\end{array}$ & $\begin{array}{l}\text { yks. } 1 . \\
\text { yks. } 2 . \\
\text { yks. } 3 . \\
\text { mon. } 1 . \\
\text { mon. } 2 . \\
\text { mon. } 3 .\end{array}$ & $\begin{array}{l}\text { laula|n } \\
\text { laula|d } \\
\text { laula|b } \\
\text { laula|me } \\
\text { laula|te } \\
\text { laula|vad } \\
\end{array}$ & $\begin{array}{l}\text { laul|si|n } \\
\text { laul|si|d } \\
\text { laul|is } \\
\text { laul|si|me } \\
\text { laul|si|te } \\
\text { laul|si|d }\end{array}$ \\
\hline $\begin{array}{l}\text { Kaksivartaloiset } \\
\text { astevaihteluverbit } \\
\text { (tundma 'tuntea') }\end{array}$ & $\begin{array}{l}\text { yks. } 1 . \\
\text { yks. } 2 . \\
\text { yks. } 3 . \\
\text { mon. } 1 . \\
\text { mon. } 2 . \\
\text { mon. } 3 .\end{array}$ & $\begin{array}{l}\text { tunne|n } \\
\text { tunne|d } \\
\text { tunne|b } \\
\text { tunne|me } \\
\text { tunne|te } \\
\text { tunne|vad }\end{array}$ & $\begin{array}{l}\text { tund|si|n } \\
\text { tund|si|d } \\
\text { tund|is } \\
\text { tund|si|me } \\
\text { tund|si|te } \\
\text { tund|si|d }\end{array}$ \\
\hline $\begin{array}{l}\text { Astevaihteluttomat } \\
\text { verbit, joilla on } \\
\text { i-imperfekti } \\
\text { (tulema 'tulla') }\end{array}$ & $\begin{array}{l}\text { yks. } 1 . \\
\text { yks. } 2 . \\
\text { yks. } 3 . \\
\text { mon. } 1 . \\
\text { mon. } 2 . \\
\text { mon. } 3 .\end{array}$ & $\begin{array}{l}\text { tule|n } \\
\text { tule|d } \\
\text { tule|b } \\
\text { tule|me } \\
\text { tule|te } \\
\text { tule|vad }\end{array}$ & $\begin{array}{l}\text { tul|i|n } \\
\text { tul|i|d } \\
\text { tul|i } \\
\text { tul|i|me } \\
\text { tul|i|te } \\
\text { tul|i|d }\end{array}$ \\
\hline
\end{tabular}




\begin{tabular}{|l|l|l:l|}
\hline $\begin{array}{l}\text { Astevaihteluverbit, joilla } \\
\text { on } i \text {-imperfekti (tegema } \\
\text { 'tehdä) }\end{array}$ & yks. 1. & tee $\mid \mathrm{n}$ & teg $|\mathrm{i}| \mathrm{n}$ \\
& yks. 2. & tee $\mid \mathrm{d}$ & teg $|\mathrm{i}| \mathrm{d}$ \\
& yks. 3. & tee $\mid \mathrm{b}$ & teg $\mid \mathrm{i}$ \\
& mon. 1. & tee $\mid \mathrm{me}$ & teg $|\mathrm{i}| \mathrm{me}$ \\
& mon. 2. & tee $\mid$ te & teg $|\mathrm{i}| \mathrm{te}$ \\
& tee $\mid \mathrm{vad}$ & teg $|\mathrm{i}| \mathrm{d}$ \\
\hline
\end{tabular}

Koska virossa useimpien verbien imperfekti muodostetaan käyttämällä vartaloon suoraan liittyvää si-tunnusta, ei preesens- ja imperfektiparadigmojen välillä tällöin ole suomen vartalovokaalin muutosten kaltaista eroa. Preesens- ja imperfektimuodot voivat kuitenkin muista syistä erota huomattavasti toisistaan. Yksinkertaisimmillaan preesens ja imperfekti muodostetaan samanlaisesta vartalosta; tällainen paradigma on yksivartaloisilla astevaihteluttomilla verbeillä (elama-tyyppi). Heikkenevän astevaihtelun alaisilla verbeillä (lugema-tyyppi) heikkoasteiset preesensvartalot poikkeavat vahva-asteisista imperfektivartaloista. Aikamuotojen välisiä eroja on myös kaksivartaloisilla verbeillä, joiden preesensmuodot ovat vokaalivartaloisia mutta joiden imperfektimuodoissa tunnus liittyy sisäheiton kautta syntyneeseen konsonanttiloppuiseen vartaloon (laulma-tyyppi). Jos kaksivartaloinen verbi on astevaihtelussa, preesens- ja imperfektimuotoja erottaa myös preesensin heikkoasteisuus ja imperfektin vahva-asteisuus (tundma-tyyppi). Pienellä joukolla $i$-imperfektin mukaan taipuvia verbejä aikamuodot eroavat toisistaan tunnuksen edellä tapahtuneiden äänteenmuutosten vuoksi (tulema-tyyppi), ja lisäksi astevaihteluverbeillä vahva-asteisuus erottaa imperfektiä preesensistä (tegema-tyyppi). Kokonaisuudessaan viron verbiparadigmat ovat selvästi inkerinsuomea yhtenäisempiä, sillä kaikissa verbityypeissä paradigmat ovat samantyyppisiä: eroja ilmenee ainoastaan preesens- ja imperfektivartaloiden välillä. 


\section{Kompleksiset verbiparadigmat attritoituvassa inkerinsuomessa}

Tutkimusaineistoni koostuu 1990-luvulla tehdyistä haastatteluista, joita on yhteensä noin 30 tuntia 37 henkilöltä. Informantit olivat syntyneet 1900-luvun alussa Inkerinmaalla ja päätyneet Viroon toisen maailmansodan jälkeen; haastatteluhetkellä he olivat asuneet vironkielisessä ympäristössä noin 50 vuotta. (Inkerinsuomalaisten taustoista ja tutkimusaineistosta tarkemmin ks. Riionheimo 2007: 23-33, 36-48). Tätä tutkimusta varten kokosin aineistosta viiden kompleksisimman eli eniten äännevaihteluita sisältävän verbityypin (tulla, jakaa, lukea, kulkea ja tietää; ks. edellä lukua 3.1) myönteiset preesens- ja imperfektimuodot ja valitsin jokaisesta tyypistä tarkemmin tarkasteltaviksi yhden tai kaksi suurtaajuisinta verbiä. Näissä verbeissä esiintyvää taivutusmuotojen variaatiota on alempana kuvattu asetelmissa, joissa on ryhmitelty erikseen alkuperäistä taivutusta noudattavat ja siitä poikkeavat muodot. Jokaisen verbityypin yhteydessä käsittelen ensin mahdollisia muutoksia preesens- ja imperfektimuotojen välillä ja sen jälkeen niitä äännevaihteluita, jotka synnyttävät persoonamuotojen välisiä eroja.

Verbityypin tulla vaihteluita ovat vartalovokaalin kato, yleisgeminaatio ja labiaalistuminen, ja tätä tyyppiä edustavat analyysissa suurtaajuinen tulla sekä jonkin verran vähemmän esiintyvä mennä (ks. asetelmia $5 \mathrm{a}$ ja 5b). Kummankin verbin taivutuksessa vartalovokaalin kato toteutuu poikkeuksetta, ja jos verbiä on taivutettu imperfektissä $s i$-tunnuksen avulla, uusi suffiksi on liitetty $i$-tunnuksen perään (pleonastista imperfekteistä tarkemmin Riionheimo 2007: 192-196). Tässä yhteydessä on huomattava, että viron tulema taipuu imperfektissä $i$-tunnuksisena ja mennä-verbin vironkielisenä vastineena on sekaparadigma, jossa preesens- ja imperfektimuodoissa käytetään suomen lähteä-verbin vastinetta. Viro ei siten tarjoa kummallekaan verbille suoraa si-tunnuksista mallia, joka mahdollistaisi samalla vartolovokaalin säilymisen. Sen sijaan preesensin 3. persoonissa esiintyy melko usein poikkeamia, joita voi pitää paradigmaa yksinkertaistavina. 
Asetelma 5a. Tulla-verbin preesens- ja imperfektimuodot frekvensseineen

\begin{tabular}{|c|c|c|c|c|}
\hline \multirow{2}{*}{ tulla } & \multicolumn{2}{|c|}{ preesens } & \multicolumn{2}{|c|}{ imperfekti } \\
\hline & alkuperäiset & muuttuneet & alkuperäiset & muuttuneet \\
\hline Yks. 1. p. & tulen (35) & & $\begin{array}{l}\text { tulin } \sim \text { tulin } \\
(182)\end{array}$ & tullin (1) \\
\hline Yks. 2.p. & tulet $\sim$ tule $(11)$ & & tulit (12) & tullit (1) \\
\hline \multirow[t]{3}{*}{ Yks. 3. p. } & \multirow[t]{3}{*}{$\begin{array}{l}\text { tulloo } \sim \text { tullo } \\
(75)\end{array}$} & $\begin{array}{l}\text { tullee } \sim \text { tulle }(5) \\
\text { tulleep } \sim \text { tullep }(2)\end{array}$ & \multirow[t]{3}{*}{ tul tuli $(655)$} & \multirow[t]{3}{*}{$\begin{array}{l}\text { tulis (3) } \\
\text { tulli (16) }\end{array}$} \\
\hline & & $\begin{array}{l}\text { tuloo }(2) \\
\text { tulloop (1) }\end{array}$ & & \\
\hline & & $\begin{array}{l}\text { tulee } \sim \text { tule }(25) \\
\text { tulep } \sim \text { tuleep }(51)\end{array}$ & & \\
\hline Mon. 1. p. & $\begin{array}{l}\text { tulem } \sim \text { tuleme } \\
\sim \text { tulemma } \sim \\
\text { tulemme }(24)\end{array}$ & & $\begin{array}{l}\text { tulim } \sim \text { tulima } \\
\sim \text { tulime } \sim \\
\text { tulimma } \sim \\
\text { tulimme } \sim \\
\text { tulimmo } \sim \\
\text { tulimo }(278)\end{array}$ & \\
\hline Mon. 2. p. & $\begin{array}{l}\text { tuletta tulette } \\
(8)\end{array}$ & & $\begin{array}{l}\text { tulitta } \sim \text { tulitte } \\
\sim \text { tulit }(11)\end{array}$ & \\
\hline \multirow[t]{2}{*}{ Mon. 3. p. } & \multirow{2}{*}{$\begin{array}{l}\text { tulloot } \sim \text { tullot } \\
\sim \text { tulloovat }(23)\end{array}$} & tullet (1) & \multirow{2}{*}{$\begin{array}{l}\text { tullit } \sim \text { tulliit } \\
(90)\end{array}$} & \multirow{2}{*}{$\begin{array}{l}\text { tulit } \sim \text { tuliit } \\
(56) \\
\text { tulivat }(57)\end{array}$} \\
\hline & & tulevat (23) & & \\
\hline
\end{tabular}

Poikkeamat jakautuvat erilaisiksi tyypeiksi: joskus muodosta puuttuu labiaalistuminen, vaikka geminaatio on säilynyt (tullee, männee), joskus taas geminaatio puuttuu mutta vartalovokaali on labiaalistunut (tuloo). Joskus molemmat vaihtelut ovat jääneet pois (tulee tulep, menee), ja tällöin muotojen mallina voi olla suomen yleiskieli tai viro. Monikon 3. persoonan preesensmuodoissa äännevaihtelut jäävät pois silloin, kun muodossa on $v A t$-pääte; tällöin mallina voivat jälleen olla sekä suomen yleiskieli että viro. Lisäksi molempien verbien taivutuksessa on muutamissa tapauksissa geminaatiota 1. ja 2. persoonan muodoissa sekä imperfektin yksikön 3. persoonassa, joihin se ei inkerinsuomessa kuulu (tullin, tullit, tulli; männin, männi). Nämä muodot ovat kaksitulkintaisia: 
ne voivat aiheutua inkerinsuomen yleisgeminaation toteutumisesta alkuperäisestä poikkeavassa äänneympäristössä (lyhyen vokaalin edellä), mutta mallina on voinut olla myös viron etelämurteissa esiintyvä suomen geminaation tapainen äännevaihtelu (Riionheimo 2007: 245-246).

Asetelma 5b. Mennä-verbin preesens- ja imperfektimuodot frekvensseineen

\begin{tabular}{|c|c|c|c|c|}
\hline \multirow{2}{*}{ mennä } & \multicolumn{2}{|c|}{ preesens } & \multicolumn{2}{|c|}{ imperfekti } \\
\hline & alkuperäiset & muuttuneet & alkuperäiset & muuttuneet \\
\hline Yks. 1.p. & $\begin{array}{l}\text { menen } \sim \text { meen } \sim \\
\text { mänen } \sim \text { mään } \\
(16)\end{array}$ & & $\begin{array}{l}\text { meni } \sim \text { menin } \sim \\
\text { mäni } \sim \text { mänin }(43)\end{array}$ & $\begin{array}{l}\text { männin (1) } \\
\text { mänisin (1) }\end{array}$ \\
\hline Yks. 2. p. & $\begin{array}{l}\text { menet } \sim \text { mänet } \\
(4)\end{array}$ & & menit $\sim$ mänit $(3)$ & \\
\hline \multirow[t]{2}{*}{ Yks. 3. p. } & \multirow{2}{*}{$\begin{array}{l}\text { mennööo } \\
\text { mennö } \sim \\
\text { männöö } ~ \\
\text { männö }(18)\end{array}$} & männee (1) & \multirow{2}{*}{$\begin{array}{l}\text { men } \sim \text { meni } \sim \text { män } \\
\sim \text { mäni }(94)\end{array}$} & männi (1) \\
\hline & & $\begin{array}{l}\text { menee (13) } \\
\text { mäneep (1) }\end{array}$ & & mänis (1) \\
\hline Mon. 1.p. & $\begin{array}{l}\text { mänem } \\
\text { mänemme } \\
\text { mänemmä (4) }\end{array}$ & & $\begin{array}{l}\text { menim } \sim \text { menime } \\
\sim \text { menimme } \sim \\
\text { menimmä } \sim \\
\text { mänim } \sim \text { mänime } \\
\sim \text { mänimme } \sim \\
\text { mänimmä }(43)\end{array}$ & \\
\hline Mon. 2. p. & $\begin{array}{l}\text { menette } \sim \text { mänet } \\
(3)\end{array}$ & & & \\
\hline \multirow[t]{2}{*}{ Mon. 3. p. } & \multirow{2}{*}{$\begin{array}{l}\text { mennöööt } \\
\text { männööot (9) }\end{array}$} & \multirow{2}{*}{$\begin{array}{l}\text { menet (1) } \\
\text { menevät (2) }\end{array}$} & \multirow{2}{*}{$\begin{array}{l}\text { menniit } \sim \text { männiit } \\
\sim \text { männit } \sim(22)\end{array}$} & männiivät (1) \\
\hline & & & & $\begin{array}{l}\text { menit } \sim \text { mänit } \\
\sim \text { mäniit }(11) \\
\text { menivät } \sim \\
\text { mänivät }(7)\end{array}$ \\
\hline
\end{tabular}


Verbityypin jakaa taivutuksessa ilmenevät vartalovokaalin kato, astevaihtelu ja yleisgeminaatio. Tämän tyypin verbeistä vain pitää on aineistossa tarpeeksi suurtaajuinen paradigman tarkastelua varten (ks. asetelmaa 6). Verbin vironkielistä vastinetta pidama taivutetaan imperfektissä nesessiiviverbinä (merkityksessä 'täytyä) $i$-tunnuksen ja muissa merkityksissä si-tunnuksen avulla, ja viron si-imperfektin olemassaolo on ehkä syynä siihen, että inkerinsuomen aineistossakin on jonkin verran si-imperfektejä (pitäsin, pitäs, pitäsimme, pitäsiit). Tällöin vartalovokaali on säilynyt, minkä ansiosta preesens- ja imperfektivartalot ovat yhdenmukaisempia, ja lisäksi kaikki imperfektin persoonamuodot ovat vahva-asteisia eli vartaloltaan samanlaisia. Persoonamuotojen välisiä eroja tasoittavat eräät muutkin muutokset.

Asetelma 6. Pitää-verbin preesens- ja imperfektimuodot frekvensseineen

\begin{tabular}{|c|c|c|c|c|}
\hline \multirow{2}{*}{ pitää } & \multicolumn{2}{|c|}{ preesens } & \multicolumn{2}{|c|}{ imperfekti } \\
\hline & alkuperäiset & muuttuneet & alkuperäiset & muuttuneet \\
\hline \multirow[t]{2}{*}{ Yks. 1. p. } & \multirow[t]{2}{*}{ piän peän $(3)$} & \multirow[t]{2}{*}{ pitän (1) } & \multirow[t]{2}{*}{ piin (1) } & pitin (22) \\
\hline & & & & pitäsin (1) \\
\hline Yks. 2.p. & piät $\sim$ peat $(6)$ & & & pitit (10) \\
\hline \multirow[t]{2}{*}{ Yks. 3. p. } & \multirow[t]{2}{*}{ pittää pittää (66) } & $\begin{array}{l}\text { pitää pitä (9) } \\
\text { pitäp (1) }\end{array}$ & \multirow[t]{2}{*}{ piti pit (181) } & \multirow[t]{2}{*}{$\begin{array}{l}\text { pitäsi } \\
\text { pitäs (7) }\end{array}$} \\
\hline & & piäp peäp (29) & & \\
\hline \multirow[t]{2}{*}{ Mon. 1. p. } & \multirow[t]{2}{*}{$\begin{array}{l}\text { piäm piämmä } \\
\text { piämä (3) }\end{array}$} & & \multirow[t]{2}{*}{$\begin{array}{l}\text { pitimme } \sim \\
\text { pitime } \sim \text { pitim } \\
(29)\end{array}$} & $\begin{array}{l}\text { pitäsimme } \\
\sim \text { pitäsime } ~ \\
\text { pitäsim }(3)\end{array}$ \\
\hline & & & & $\begin{array}{l}\text { pitisimme } \\
\text { (1) }\end{array}$ \\
\hline Mon. 2. p. & $\begin{array}{l}\text { piätte } \sim \text { piättä } ~ \\
\text { piette } \sim \text { piät }(7)\end{array}$ & pitätte (1) & & \\
\hline \multirow[t]{2}{*}{ Mon. 3. p. } & \multirow[t]{2}{*}{ pittäät (1) } & pitävät (1) & \multirow[t]{2}{*}{$\begin{array}{l}\text { pittiit } \sim \text { pittit } \\
(23)\end{array}$} & $\begin{array}{l}\text { pitivät (4) } \\
\text { pitit (6) }\end{array}$ \\
\hline & & $\begin{array}{l}\text { peävät piävät } \\
\text { (3) }\end{array}$ & & $\begin{array}{l}\text { pitäsiit } \\
\text { pitäsit (7) }\end{array}$ \\
\hline
\end{tabular}


Ensinnäkin preesensin 3. persoonissa on viroa muistuttavia heikkoasteisia muotoja (piäp peäp, peävät piävät) ja toiseksi imperfektissä on 1. ja 2. persoonissa runsaasti vahva-asteisia $i$-imperfektimuotoja (pitin, pitit); molemmissa tapauksissa asteyleistyksen suunta on samanlainen kuin virossa. Huomiota kiinnittävät muutamat $t$ :lliset muodot preesensin 1. ja 2. persoonassa (pitän, pitätte), mutta nämä eivät välttämättä ole vahva-asteisia muotoja, vaan $t$ saattaa olla tulosta suomen yleiskielen mukaisen $d: n$ tavoittelusta. Lisäksi aineistossa on jonkin verran preesensmuotoja, jotka ovat muuten inkerinsuomen alkuperäisen verbintaivutuksen mukaisia mutta joissa yleisgeminaatio on tasoittunut (pitää).

Tyypille lukea ovat ominaisia vartalovokaalin kato, astevaihtelu, yleisgeminaatio ja labiaalistuminen. Tästä tyypistä tarkasteltavana ovat suurtaajuinen tehdä, jonka vironkielinen vastine taipuu $i$-imperfektissä, ja harvinaisempi lukea, jolla on virossa si-imperfektin mukaan taipuva vastine (ks. asetelmia $7 \mathrm{a}$ ja $7 \mathrm{~b}$ ). Vartalovokaalin säilymistä esiintyy lukea-verbin si-tunnuksisissa imperfektimuodoissa (lukesin, lukesit) ja kerran lipsahduksenomaisesti $i$-imperfektissä (luveimme). Tehdä-verbin imperfektissä vastaavia muotoja ei ole, vaan jos verbiä on taivutettu $s i$-tunnuksen avulla, tunnus on liitetty $i$-tunnuksisen imperfektivartalon perään (tekis, tekisimme). Labiaalistuminen on muutamissa tapauksissa tasoittunut preesensin yksikön 3. persoonassa; joskus geminaatio on silti säilynyt (tekkee) mutta usein myös geminaatio on samalla tasoittunut (tekee, lukee). Lisäksi monikon 3. persoonan muodoissa on jonkin verran $v A t$-päätteisiä muotoja (tekevät, tekivät; lukivat), joissa äännevaihtelut eivät pääse toteutumaan. Astevaihtelu käyttäytyy kahtalaisesti: yhtäältä ilmenee viron kielen mukaisia muutoksia eli jonkin verran preesensmuotojen heikkoasteisuutta (tee $\sim$ teep $\sim$ tiep, luvep) ja runsaasti vahvan asteen yleistymistä imperfektissä (tekin, tekimme, lukin), mutta toisaalta preesensin 1. ja 2. persoonissa esiintyy joitain virosta poikkeavia vahvaasteisia muotoja (teken, tekemme), jotka saattavat osoittaa pyrkimystä yhdenmukaistaa preesensparadigmoja astevaihtelusta luopumalla. 
Asetelma 7a. Tehdä-verbin preesens- ja imperfektimuodot frekvensseineen

\begin{tabular}{|c|c|c|c|c|}
\hline \multirow{2}{*}{ tehdä } & \multicolumn{2}{|c|}{ preesens } & \multicolumn{2}{|c|}{ imperfekti } \\
\hline & alkuperäiset & muuttuneet & alkuperäiset & muuttuneet \\
\hline Yks. 1.p. & teen $\sim$ tien $(13)$ & teken (1) & tein $(9)$ & tekin (29) \\
\hline Yks. 2.p. & teet $\sim$ tiet $(11)$ & & & tekit (4) \\
\hline \multirow[t]{3}{*}{ Yks. 3. p. } & \multirow{3}{*}{ 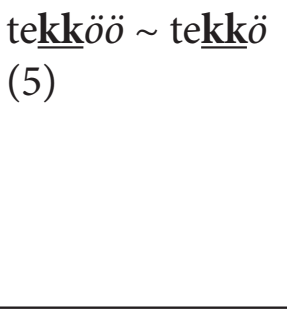 } & tekkee $\sim$ tekke $(2)$ & \multirow[t]{3}{*}{ tek $\sim$ teki $(57)$} & \multirow{3}{*}{$\begin{array}{l}\text { tekis (1) } \\
\text { tekkis (2) }\end{array}$} \\
\hline & & $\begin{array}{l}\text { tekee }(3) \\
\text { tekep }(1)\end{array}$ & & \\
\hline & & $\begin{array}{l}\text { tee }(1) \\
\text { teep } \sim \text { tiep }(5)\end{array}$ & & \\
\hline \multirow[t]{2}{*}{ Mon. 1. p. } & \multirow[t]{2}{*}{ tiemme (2) } & \multirow[t]{2}{*}{$\begin{array}{l}\text { tekeme } ~ \\
\text { tekemme (3) }\end{array}$} & \multirow[t]{2}{*}{$\begin{array}{l}\text { teimme } \sim \text { teime } \\
\sim \text { teim }(4)\end{array}$} & $\begin{array}{l}\text { tekimme } \sim \\
\text { tekime } \sim \text { tekim } \\
(42)\end{array}$ \\
\hline & & & & $\begin{array}{l}\text { tekisimme } ~ \\
\text { tekisim }(2)\end{array}$ \\
\hline Mon. 2. p. & tiette (2) & & & tekitte (2) \\
\hline \multirow[t]{2}{*}{ Mon. 3. p. } & \multirow[t]{2}{*}{ tekköööt (4) } & teevät tievät $(4)$ & \multirow{2}{*}{$\begin{array}{l}\text { tekkiit } \sim \text { tekkit } \\
(28)\end{array}$} & \multirow{2}{*}{$\begin{array}{l}\text { tekiit } \sim \text { tekit } \\
(11) \\
\text { tekivät }(15)\end{array}$} \\
\hline & & $\begin{array}{l}\text { tekevät (2) } \\
\text { tehevät (1) }\end{array}$ & & \\
\hline
\end{tabular}

Asetelma 7b. Lukea-verbin preesens- ja imperfektimuodot frekvensseineen

\begin{tabular}{|c|c|c|c|c|}
\hline \multirow{2}{*}{ lukea } & \multicolumn{2}{|c|}{ preesens } & \multicolumn{2}{|c|}{ imperfekti } \\
\hline & alkuperäiset & muuttuneet & alkuperäiset & muuttuneet \\
\hline \multirow[t]{2}{*}{ Yks. 1.p. } & \multirow[t]{2}{*}{ luen $\sim$ luven $(17)$} & & \multirow{2}{*}{$\begin{array}{l}\text { luin } \sim \text { luvin } ~ \\
\text { lui }(10)\end{array}$} & lukesin (3) \\
\hline & & & & lukin (2) \\
\hline Yks. 2. p. & luvet $\sim$ luve (4) & & & lukesit (1) \\
\hline \multirow[t]{2}{*}{ Yks. 3. p. } & \multirow[t]{2}{*}{ lukk $o o$ (5) } & lukee (1) & \multirow[t]{2}{*}{ luki (2) } & lukes (1) \\
\hline & & luvep (3) & & luvi (1) \\
\hline Mon. 1.p. & $\begin{array}{l}\text { lueme } \sim \\
\text { luvemma (2) }\end{array}$ & & $\begin{array}{l}\text { luimme } ~ \\
\text { luvim } \sim \\
\text { luvimma (3) }\end{array}$ & luveimme (1) \\
\hline \multicolumn{5}{|l|}{ Mon. 2.p. } \\
\hline Mon. 3. p. & lukk koot (1) & & lukkiit (1) & lukivat (1) \\
\hline
\end{tabular}


Verbityypin kulkea ominaisuuksiin kuuluvat vartalovokaalin kato, astevaihtelu ja labiaalistuminen. Tämän tyypin verbeistä ainoa tarpeeksi suurtaajuinen on lähteä, jonka paradigma on inkerinsuomessa poikkeuksellinen: verbin imperfektimuodot ovat läksi-vartaloisia. Asetelma 8 osoittaa, että aineistossa ilmenee muutamassa tapauksessa pyrkimystä pois läksi-vartaloisista imperfekteistä (lähtin, lähti, lähtimme) eli preesens- ja imperfektivartaloiden yhdenmukaistumista. Labiaalistuminen jää preesensissä joskus toteutumatta (lähtee, lähteet), ja usein tällaiset muodot ovat viron kielen kaltaisia eli heikkoasteisia (lähep, lähevät; tähän voidaan laskea myös viron lyhentymämuotojen tapaiset lähme ja lähvät). Astevaihtelun suhteen suunta on siis samanlainen kuin edellä käsitellyissä verbeissä: heikkoasteisuutta esiintyy preesensin 3. persoonan muodoissa. Poikkeavia t:llisiä muotoja on 1. ja 2. persoonissa (lähten, lähtemme, lähtin, lähtimme), mutta näissä selityksenä voi olla myös suomen yleiskielen $d: 1 l i s e n$ ääntämyksen tavoittelu.

Asetelma 8. Lähteä-verbin preesens- ja imperfektimuodot frekvensseineen

\begin{tabular}{|c|c|c|c|c|}
\hline \multirow{2}{*}{ lähteä } & \multicolumn{2}{|c|}{ preesens } & \multicolumn{2}{|c|}{ imperfekti } \\
\hline & alkuperäiset & muuttuneet & alkuperäiset & muuttuneet \\
\hline Yks. 1. p. & $\begin{array}{l}\text { lähen lähän } \\
\text { (38) }\end{array}$ & lähten (4) & 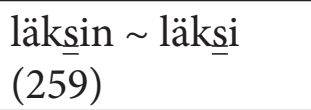 & lähtin (3) \\
\hline Yks. 2.p. & lähet lähät (31) & lähtet (2) & läksit (7) & \\
\hline \multirow{2}{*}{ Yks. 3. p. } & \multirow{2}{*}{$\begin{array}{l}\text { lähtöö lähtö } \\
\text { (11) }\end{array}$} & lähtee lähte (3) & \multirow[t]{2}{*}{ 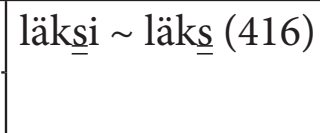 } & lähti (5) \\
\hline & & lähep lähäp (18) & & läksis (3) \\
\hline \multirow{2}{*}{ Mon. 1. p. } & \multirow{2}{*}{$\begin{array}{l}\text { lähemme } \\
\text { läheme lähem } \\
\text { lähemä } \\
\text { lähäm (17) }\end{array}$} & $\begin{array}{l}\text { lähtemme } \\
\text { lähtem (5) }\end{array}$ & \multirow{2}{*}{$\begin{array}{l}\text { läksimme } \\
\text { läksimmä } \\
\text { läksimmö } \\
\text { läksim läksime } \\
\text { läksimä (223) }\end{array}$} & $\begin{array}{l}\text { lähtimme } \\
\text { (3) }\end{array}$ \\
\hline & & lähme (11) & & lähimme (1) \\
\hline Mon. 2. p. & $\begin{array}{l}\text { lähhette lähettä } \\
\sim \text { lähätte (6) }\end{array}$ & & & \\
\hline \multirow{3}{*}{ Mon. 3. p. } & \multirow[t]{3}{*}{ lähtööt (2) } & lähteet (2) & \multirow{3}{*}{$\begin{array}{l}\text { läksiiit läksit } \\
(120)\end{array}$} & \multirow{3}{*}{$\begin{array}{l}\text { läksiviät } \\
\text { läkșiivät (7) }\end{array}$} \\
\hline & & $\begin{array}{l}\text { lähet (1) } \\
\text { lähevät (4) }\end{array}$ & & \\
\hline & & lähvät (2) & & \\
\hline
\end{tabular}


Lopuksi otan vielä esille verbityypin tietää, jonka taivutukseen kuuluvat astevaihtelu, vartalovokaalin kato ja $t \sim s$-vaihtelu. Tämän tyypin verbit eivät ole aineistossa kovin suurtaajuisia, joten myös tässä tarkasteltujen verbien tietää ja löytää paradigmoissa on aukkoja (ks. asetelmia 9a ja 9b). Näiden verbien keskeisin ominaispiirre on $t \sim s$-vaihtelu preesens- ja imperfektimuotojen välillä, ja muutamat aineistossa esiintyvät vahvaan vokaalivartaloon pohjautuvat $s i$-imperfektin muodot (tietäsin, tietäs; löytäsin, löytäsimme) voivat olla merkkejä siitä, että puhujat pyrkivät käyttämään imperfektissä samanlaista vartaloa kuin preesensissä; $s i$-imperfekteissähän jäävät toteutumatta kaikki verbityypille muuten ominaiset äännevaihtelut. Toinen muutostendenssi on samansuuntainen kuin muillakin astevaihteluverbeillä: preesensin 3. persoonissa esiintyy viron aiheuttamaa heikkoasteisuutta (tie teap, tievät, leiap). Yksikön 1. persoonien poikkeukselliset $t$ :lliset muodot (tietän, löytän) voivat olla tässäkin tapauksessa joko poikkeuksellista vahva-asteisuutta tai suomen yleiskielen $d:$ n tavoittelua.

Asetelma 9a. Tietää-verbin preesens- ja imperfektimuodot frekvensseineen

\begin{tabular}{|c|c|c|c|c|}
\hline \multirow{2}{*}{ tietää } & \multicolumn{2}{|c|}{ preesens } & \multicolumn{2}{|c|}{ imperfekti } \\
\hline & alkuperäiset & muuttuneet & alkuperäiset & muuttuneet \\
\hline Yks. 1.p. & $\begin{array}{l}\text { tiijjän } \sim \text { tiiän } \sim \text { tiij- } \\
\text { jen } \sim \text { tiän } \sim \text { tien }(9) \\
\text { tean } \sim \text { tea }(2)\end{array}$ & tietän (13) & tiesin (9) & tietäsin (1) \\
\hline Yks. 2. p. & $\begin{array}{l}\text { tiijjät } \sim \text { tiiät } \sim \text { tiät } \\
(46)\end{array}$ & $\begin{array}{l}\text { teat } \sim \text { teät }(7) \\
\text { tiet }(5)\end{array}$ & & \\
\hline \multirow[t]{2}{*}{ Yks. 3. p. } & \multirow[t]{2}{*}{ tietää tietä $(9)$} & tie (1) & \multirow[t]{2}{*}{ ties $\underline{\underline{i}} \sim$ ties $(12)$} & \multirow[t]{2}{*}{ tietäs (1) } \\
\hline & & teap $(1)$ & & \\
\hline Mon. 1.p. & tiäme tiäm $(2)$ & & $\begin{array}{l}\text { tiesimme } \sim \\
\text { tiesim }(4)\end{array}$ & tietäsimme (1) \\
\hline Mon. 2. p. & $\begin{array}{l}\text { tiätte } \sim \text { tiäte } \sim \text { tieätte } \\
\sim \text { tiiätte } \sim \text { tiiättä }(10) \\
\text { teatte }(2)\end{array}$ & & & \\
\hline Mon. 3. p. & tietäät (1) & tievät (1) & $\begin{array}{l}\text { tiesiit } \sim \text { tiesit } \\
(6)\end{array}$ & $\begin{array}{l}\text { tiesivät } \\
\text { tiessivät (3) }\end{array}$ \\
\hline
\end{tabular}


AsETELMA 9b. Löytää-verbin preesens- ja imperfektimuodot frekvensseineen

\begin{tabular}{|c|c|c|c|c|}
\hline \multirow{2}{*}{ löytää } & \multicolumn{2}{|c|}{ preesens } & \multicolumn{2}{|c|}{ imperfekti } \\
\hline & alkuperäiset & muuttuneet & alkuperäiset & muuttuneet \\
\hline Yks. 1. p. & löyvvän (1) & löytän (2) & löysin (9) & löytäsin (1) \\
\hline Yks. 2.p. & & leiat (1) & löysit & \\
\hline Yks. 3.p. & löytää (2) & leiap (1) & 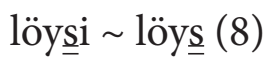 & löytiis (1) \\
\hline Mon. 1.p. & löyvämme (1) & & $\begin{array}{l}\text { löysimme } \\
\text { löysime (4) }\end{array}$ & $\begin{array}{l}\text { löytäsimme } \\
(1)\end{array}$ \\
\hline Mon. 2.p. & löyvätte (1) & & & \\
\hline Mon. 3.p. & & & $\begin{array}{l}\text { löysiit löysit } \\
\text { (2) }\end{array}$ & \\
\hline
\end{tabular}

Yhteenvetona voidaan ensinnäkin todeta, että edellä kuvattujen verbien taivutuksessa esiintyy jonkin verran sellaisia muutoksia, jotka johtavat preesens- ja imperfektivartaloiden yhdenmukaistumiseen. Tällaisia tapauksia ovat vokaalivartaloon perustuvat $s i$-imperfektit, joissa jää toteutumatta vartalovokaalin kato ja vartalon $t$ :n muuttuminen $s$ :ksi. $s i$-imperfektiä esiintyy lähinnä silloin, kun verbillä on virossa $s i$-imperfektissä taipuva vastine, ja jos muilla verbeillä on $s i$-tunnuksisia imperfektejä, tunnus liittyy niissä alkuperäisen $i$-tunnuksen perään ja vokaalinvaihtelu säilyy. Toisensuuntaista preesensiä ja imperfektiä yhtenäistävää tendenssiä ilmenee lähteä-verbin taivutuksessa, kun muutamissa tapauksissa käytetään (suomen yleiskielen mukaista) vokaalivartaloon perustuvaa $i$-imperfektiä (esim. lähti). Tällaiset poikkeamat ovat kuitenkin aineistossa harvinaisia, ja preesens- ja imperfektiparadigmojen väliset äänteelliset erot eivät vaikuta sellaiselta kompleksisuudelta, joka olisi tässä kontakti- ja attritiotilanteessa erityisen altis yksinkertaistumiselle.

Toisena tarkastelukohteena ovat tässä luvussa olleet persoonamuotojen väliset erot, joita aiheuttavat inkerinsuomessa yhtäl̈ltä 3. persoonissa toteutuvat yleisgeminaatio ja labiaalistuminen ja toisaalta 1 . ja 2. persoonissa näkyvä astevaihteluverbien heikkoasteisuus. Aineisto osoittaa selvästi, että sekä geminaatio että labiaalistuminen ovat suhteellisen alttiita muutoksille, sillä kaikilla niillä verbeillä, joiden taivutukseen ne 
kuuluvat, esiintyy tasoittuneita muotoja. Joskus pois jää labiaalistuminen, joskus yleisgeminaatio, joskus taas molemmat näistä vaihteluista. Molemmat vaihtelut jäävät toteutumatta myös silloin, kun puhuja käyttää inkerinsuomesta poikkeavaa persoonapäätettä (yksikön 3. persoonassa - $p$ ja monikon 3. persoonassa $-v A t)$. Tasoittuminen johtaa persoonaparadigmojen yhdenmukaistumiseen, mutta ei ole selvää, motivoiko muutosta yksinkertaistuminen vai se, että nämä vaihtelut puuttuvat kahdesta inkerinsuomeen vaikuttaneesta kielimuodosta, suomen yleiskielestä ja virosta.

Astevaihteluverbeillä ilmenee aineistossa kahdenlaisia muutoksia. Ensinnäkin kaikilla käsitellyillä verbeillä näkyy astevaihtelun tasoittumista persoonamuodoittain viron kielen mallin mukaisesti siten, että preesensissä alun perin vahva-asteiset 3 . persoonien muodot esiintyvät heikkoasteisina ja imperfektissä alun perin heikkoasteiset 1. ja 2 . persoonat vahva-asteisina. Verbeillä pitää ja tehdä vahva-asteisuus on imperfektissä huomattavan yleistä, ja näillä verbeillä tendenssi kohti vahva-asteisuutta on ehkä ollut idullaan jo vanhoissa inkerinsuomen murteissa (Riionheimo 2007: 234). Astevaihtelun tasoittuminen vahvan asteen suuntaan on näistä muutoksista odotuksenmukaisempi, ja koska vastaavaa tasoittumista ilmenee jonkin verran myös preesensin 1. ja 2. muodoissa, se voi ainakin osittain osoittaa kielensisäistä yksinkertaistumistendenssiä. Heikon asteen yleistyminen on yllättävämpää ja selvästikin viron kielen aiheuttamaa, mutta sekin voidaan tulkita persoonaparadigmoja yksinkertaistavaksi muutokseksi.

\section{Lopuksi}

Tämän artikkelin lähtökohtana ovat olleet seuraavat aikaisemman tutkimuksen oletukset: 1) vähemmistökielen ja enemmistökielen välillä voi tapahtua negatiivista lainaamista eli sellaisten vähemmistökielen piirteiden karsiutumista, joilla ei ole vastinetta enemmistökielessä (Dorian 2006), 2) yksilön ensikielen attritio voi johtaa piirteiden tai elementtien reduktioon tai yksinkertaistumiseen (Schmid 2011) ja 3) suomen 
morfologisessa järjestelmässä altteimpia muutoksille ovat sellaiset paradigmat, joissa on eniten morfofonologisia vaihteluita (Paunonen 2003: 208). Tutkimuksessani olen testannut näitä oletuksia aineistossa, joka on peräisin Viroon toisen maailmansodan jälkeen asettuneilta ja äidinkielen attritiota kokeneilta inkerinsuomalaisilta. Tarkasteltavana on ollut preesens- ja imperfektitaivutus, ja luvussa 3 esittämäni kuvaus on osoittanut, että inkerinsuomen preesens- ja imperfektiparadigmat ovat huomattavasti viron vastaavia paradigmoja kompleksisemmat. Näihin paradigmoihin voi katsoa kohdistuvan yksinkertaistumispaineita sekä dominoivan kielen että inkerinsuomen attrition suunnasta.

Aiempi tutkimukseni on osoittanut, että kokonaisuudessaan morfofonologiset vaihtelut ovat säilyneet hyvin Viron inkerinsuomalaisten puhumassa suomessa ja että havaittavissa on vain hajanaisia yksinkertaistumiseen johtavia muutoksia ja tasoittumisia (Riionheimo 2013). Tulokset ovat tukeneet attritiotutkimuksessa 2000-luvulla esitettyä oletusta siitä, että kun kompleksinen morfologia on omaksuttu lapsuuden kielenomaksumisen aikana osana äidinkieltä, se säilyy myös kielikontakti- ja attritiotilanteissa huomattavan hyvin (ks. esim. Schmid 2002). Tämä taas viittaa siihen, että attritiossa tapahtuva yksinkertaistuminen koskee ilmeisesti enemmän muita kieliopin osia kuin morfologiaa. Toisaalta tulokset osoittavat myös, että inkerinsuomen kompleksinen verbimorfologia ei kovin herkästi mukaudu viron näiltä osin yksinkertaisempaan taivutukseen, vaikka viro on ollut informanttien elämässä vuosikymmenten ajan hallitseva kieli.

Tässä artikkelissa esittämäni analyysi syventää aikaisempia kuvauksiani Viron inkerinsuomalaisten verbintaivutuksesta ja antaa yksityiskohtaisemman kuvan kompleksisten verbien käyttäytymisestä tässä kielikontaktissa. Kaikkein kompleksisimpien paradigmojen tarkempi analyysi paljastaa, että näiden verbien käytössä todellakin ilmenee jonkin verran muutoksia, joita on mahdollista pitää paradigmaa yksinkertaistavina. Verbikohtainen analyysi on siis eräänlainen täydentävä menetelmä, joka kertoo kontaktin lopputuloksesta osittain erilaisia asioita kuin yksittäisiin morfofonologisiin vaihteluihin keskittyvä 
tarkastelu. Vaikka inkerinsuomen morfofonologinen kompleksisuus näyttää yleisesti ottaen säilyneen varsin hyvin, pitää oletus kompleksisimpien paradigmojen muutosalttiudesta tämän artikkelin perusteella ainakin osittain paikkansa. Useimmat yksinkertaistumisilta näyttävät muutokset ovat samalla viron kielen mukaisia, joten on vaikeaa ja jopa mahdotonta arvioida, onko poikkeamien takana pyrkimys kohti yksinkertaisempaa paradigmaa vai viron kielen tarjoama suomesta poikkeava malli. Lähisukukielten välisessä kontaktissa monet muutokset ovat väistämättä monilähtöisiä.

Lopuksi on vielä korostettava, että kuten edellä käsitellyt esimerkkiparadigmatkin osoittavat, autenttisesta puheesta koottu aineisto sisältää hyvin paljon variaatiota. Inkerinsuomalaisten kielikontakti on johtanut murteen hajoamiseen toisistaan paljonkin poikkeaviksi idiolekteiksi, ja myös yksittäisten puhujien tuotoksissa voi olla paljon vaihtelua. Siksi aineistossa ilmeneviä yksinkertaistumisia on syytä pitää enemmänkin yksittäistapauksina kuin merkkeinä koko kielisysteemin uudenlaisesta jäsentymisestä.

\section{Kiitokset}

Kiitän artikkelin ensimmäisen version nimettömiä arvioijia heidän antamastaan hyödyllisestä palautteesta. Tutkimus on valmistunut Suomen Akatemian tutkijatohtorin hankkeen (nro 132540) aikana.

\section{Lähteet}

Anttila, Raimo 1974. Allomorfien semiotiikkaa. - Virittäjä 78, 331-337.

Dahl, Östen 2004. The Growth and Maintenance of Linguistic Complexity. Amsterdam: John Benjamins.

Dorian, Nancy C. 2006. Negative borrowing in an indigenous-language shift to the dominant national language. - International Journal of Bilingual Education and Bilingualism 9 (5), 557-577. http://dx.doi.org/10.2167/beb380.0

EKG I 1995 = Mati Erelt, Reet Kasik, Helle Metslang, Henno Rajandi, Kristiina Ross, Henn Saari, Kaja Tael, Silvi Vare 1995. Eesti keele grammatika I. 
Morfoloogia, sõnamoodustus. Tallinn: Eesti Teaduste Akadeemia Eesti Keele Instituut.

Karlsson, Fred, Matti Miestamo, Kaius Sinnemäki 2008. Introduction: The problem of language complexity. - Matti Miestamo, Kaius Sinnemäki, Fred Karlsson (Eds.). Language Complexity. Typology, Contact, Change. Amsterdam: John Benjamins, VII-XIV.

Kusters, Wouter 2003. Linguistic Complexity. The Influence of Social Change on Verbal Inflection. Utrecht: LOT.

McWhorter, John H. 2008. Why does a language undress? Strange cases in Indonesia. - Matti Miestamo, Kaius Sinnemäki, Fred Karlsson (Eds.). Language Complexity. Typology, Contact, Change. Amsterdam: John Benjamins, 167-190.

Miestamo, Matti 2008. Grammatical complexity in a cross-linguistic perspective. Matti Miestamo, Kaius Sinnemäki, Fred Karlsson (Eds.). Language Complexity. Typology, Contact, Change. Amsterdam: John Benjamins, 23-41.

Montrul, Silvina 2010. Current issues in heritage language acquisition. - Annual Review of Applied Linguistics 30, 3-23. http://dx.doi.org/10.1017/ $\underline{\text { S0267190510000103 }}$

Paunonen, Heikki 1976. Allomorfien dynamiikkaa. - Virittäjä 80, 82-107.

Paunonen, Heikki 2003. Suomen kielen morfologisista muutosmekanismeista. Lea Laitinen, Hanna Lappalainen, Päivi Markkola, Johanna Vaattovaara (Toim.). Muotojen mieli. Kirjoituksia morfologiasta ja variaatiosta. Kieli 15. Helsinki: Helsingin yliopiston suomen kielen laitos, 187-248.

Porkka, Volmari 1885. Ueber den Ingrischen Dialekt mit Berücksichtigung der übrigen finnisch-ingermanländischen Dialekte. Helsinfors: J. C. Frenckell \& Sohn.

Remes, Hannu 1983. Viron kielioppi. Porvoo: WSOY.

Remes, Hannu 2009. Muodot kontrastissa. Suomen ja viron vertailevaa taivutustypologiaa. Acta Universitas Ouluensis B Humaniora 90. Oulu: Oulun yliopisto.

Riionheimo, Helka 2007. Muutoksen monet juuret. Oman ja vieraan risteytyminen Viron inkerinsuomalaisen imperfektinmuodostuksessa. SKS:n toimituksia 1107. Helsinki: Suomalaisen Kirjallisuuden Seura.

Riionheimo, Helka 2013. Inkerinsuomen verbimorfologia kielikontaktissa ja attritiossa. - Kimmo Granqvist, Päivi Rainò (Toim.). Rapautuva kieli. Kirjoituksia vähemmistökielten kulumisesta ja kadosta. SKS:n toimituksia 1404. Helsinki: Suomalaisen Kirjallisuuden Seura, 37-75. 
Ruoppila, Veikko 1955. Äyrämöismurteiden äännehistoria. SKS:n toimituksia 245. Helsinki: Suomalaisen Kirjallisuuden Seura.

Schmid, Monika S. 2002. First Language Attrition, Use and Maintenance. The Case of German Jews in Anglophone Countries. Studies in Bilingualism 24. Amsterdam: John Benjamins

Schmid, Monika S. 2011. Language Attrition. Key Topics in Sociolinguistics. Cambridge: Cambridge University Press. http://dx.doi.org/10.1017/ CBO9780511852046

Trudgill, Peter 2011. Sociolinguistic Typology. Social Determinants of Linguistic Complexity. Oxford: Oxford University Press.

\section{Helka Riionheimo}

Itä-Suomen yliopisto, Filosofinen tiedekunta

Humanistinen osasto, suomen kieli ja kulttuuritieteet

PL 111

FI-80101 Joensuu, Finland

helka.riionheimo@uef.fi 


\title{
Paradigmatic complexity in the contact between Ingrian Finnish and Estonian
}

\author{
HELKA RIIONHEIMO \\ University of Eastern Finland
}

This article examines the maintenance of the paradigmatic complexity of Finnish verb inflection in a contact between two Finnic languages, Finnish (the Ingrian Finnish dialect) and Estonian. Here, paradigmatic complexity refers to the intricate paradigms in which historical sound changes have produced phonological differences between the paradigm members. The Ingrian Finnish and Estonian present and past tense paradigms of verb inflection are compared with each other, showing that Finnish inflection is in this respect remarkably complex compared with the Estonian inflection. On the basis of this comparison, five most complex verb types are chosen for closer analysis. The results show that even though the complexity is to a large extent maintained in the interview data, there are also signs of simplification, indicating that complex paradigms are susceptible to change. It has to be noted, however, that the simplification tendencies mostly coincide with influence from Estonian.

Keywords: morphology; morphophonology; complexity; paradigmatic; simplification; language contact; verb inflection; Ingrian Finnish; Finnish; Estonian 